\title{
Manajemen Pakan dan Analisis Profitabilitas Usaha Peternakan Sapi Potong Rakyat di Masa Pandemi Covid 19 di Kabupaten Langkat
}

${ }^{1 *}$ Ruth Dameria Haloho, ${ }^{1}$ Elvany Tarigan

${ }^{1}$ Program Studi Agribisnis, Fakultas Sains dan Teknologi Universitas Quality Berastagi *Correspondence author: ruthdameria28@gmail.com

\section{Article Info}

Article history:

Received 19 June 2021

Received in revised from 12 July 2021

Accepted 24 October 2021

DOI: https://doi.org/10.32938/ag.v6i4.1396

Keywords:

Feed Management

Profitability Analysis

Beef Cattle

Covid 19

\begin{abstract}
Abstrak
The purpose of this study is to determine the feed management and profitability of smallholder beef cattle farming. The study was conducted in Langkat Regency with a total of 80 respondents from smallholder beef cattle business. The method of the study is a survey. The data analysis used is descriptive quantitative. Data were analyzed using income analysis, profitability and One Sample T-Test using SPSS. The results showed that the management of feed, namely the feed provided only consisted of forage, feeding was given in the morning and evening and the way of feeding was the Kreman method. Based on the results of calculations during the covid 19 pandemic, the total of revenue were Rp. $16,122,500$; production cost of Rp. 12,389,581. The amount of income is Rp. $3,732,919$. Profitability value of $23.15 \%$ is greater than BRI Bank deposits of $4 \%$, so the beef cattle business is declared profitable and feasible to be developed
\end{abstract}

\section{Pendahuluan}

Salah satu penyumbang pertumbuhan perekonomian nasional adalah subsektor peternakan. Hal ini dapat dilihat dari pertumbuhan penduduk dan komsumsi pangan yang selalu meningkat (Direktorat Jenderal Peternakan dan Kesehatan Hewan, 2020). Salah satu subsektor peternakan yang memberikan kontribusi dalam perekonomian adalah ternak sapi potong. Kontribusi dari ternak sapi potong yang dikomsumsi adalah sebagai sumber protein hewani. Saat ini, jumlah permintaan protein hewani meningkat dengan cepat seperti peningkatan jumlah penduduk, peningkatan mata pencaharian dan mobilisasi penduduk (Haq et al., 2018).

Kabupaten Langkat adalah daerah yang didominasi dataran rendah dimana cocok untuk budidaya pertanian dan kawasan peternakan yaitu sapi potong. Kabupaten Langkat merupakan salah satu sentra populasi sapi potong yang berada di Sumatera Utara. Populasi sapi potong yang ada di Kabupaten Langkat berjumlah 201.840 ekor dan produksi daging sapi sebesar 95.000 ton (Dinas Ketahanan Pangan dan Peternakan Provinsi Sumatera Utara, 2019). Populasi sapi potong yang tinggi di Kabupaten Langkat merupakan potensi untuk pengembangan usaha peternakan sapi potong.

Pengembangan usaha peternakan sapi potong berada diwilayah pedesaan yang dipelihara oleh masyarakat desa baik perseorangan maupun kelompok. Pemeliharaan sapi potong masih bersifat secara tradisional (Putri et al., 2019). Peternak menjadikan usaha peternakan sapi potong rakyat sebagai usaha utama maupun sampingan selain bertani (Lestari et al., 2017). Peternak menjadikan usaha sapi potong menjadi usaha utama maupun sampingan yang mendukung pendapatan keluarga.

Salah satu faktor terbesar dari keberhasilan peternakan adalah pakan. Faktor Lingkungan mempunyai pengaruh sebesar $70 \%$ terhadap produktivitas ternak dan $30 \%$ oleh faktor genetik. Salah satu faktor lingkungan yang mempengaruhi produktivitas ternak adalah pakan. Pakan yang merupakan faktor lingkungan mempunyai pengaruh sejumlah $60 \%$ terhadap produktivitas ternak. Potensi kualitas genetik ternak dipengaruhi oleh kualitas pakan. Ternak yang mempunyai genetik yang bagus jika tidak diberi pakan yang berkualitas sangat sulit untuk mendapatkan produksi yang tinggi dari ternak tersebut (Agustini ,2010). Manajemen pakan yang baik dilihat dari pemberian pakan, jenis pakan, cara pemberian pakan dan jumlah pakan yang diberikan berpengaruh terhadap produksi ternak yang dapat meningkatkan pendapatan. Selain manajemen pakan keberhasilan usaha peternakan dalam menjalankan usaha dapat dianalisis menggunakan analisa profitabilitas agar dapat mengukur keuntungan maupun kerugian usaha tersebut (Handayanta et al., 2016).

Awal Tahun 2020 dunia mengalami pandemi Covid 19 yang berpengaruh terhadap banyak hal yang disebabkan oleh peraturan yang dibuat oleh pemerintah. Dunia peternakan mengalami dampak secara tidak langsung yaitu biaya bahan pakan dan pakan ternak. Daya beli masyarakat terhadap produk peternakan mengalami penurunan karena harga produk mengalami peningkatan akibat adanya aturan PSSB, setelah new normal diberlakukan dari pemerintah harga kembali normal (Harmen, 2020). Manajemen pakan dan analisis profitabilitas selama masa pandemi covid 19 menjadi dasar untuk melakukan penelitian ini.. Berdasarkan latar belakang diatas maka perlu diketahui manajemen pakan dan analisis profitabilitas usaha peternakan sapi 
potong rakyat ditengah masa pandemi covid 19. Tujuan dari penelitian ini adalah mengetahui manajemen pakan dan profitabilitas usaha peternakan sapi potong rakyat.

\section{Metode}

Penelitian dilaksanakan di Kecamatan Secanggang dan Wampu di Kabupaten Langkat. Penelitian berlangsung dari bulan Mei 2020. Pemilihan lokasi penelitian berdasarkan secara purposive yaitu berdasarkan pertimbangan bahwa Kecamatan Secanggang dan Wampu memiliki populasi sapi potong terbanyak di Kabupaten Langkat. Menurut Sunyoto (2009), menyatakan bahwa pengumpulan sampel secara purposive adalah metode pengumpulan sampel dengan tujuan dan maksud tertentu. Seseorang atau sesuatu yang ditarik sebagai sampel dikarenakan sesuatu atau seseorang mempunyai informasi yang dibutuhkan oleh peneliti dalam penelitiannya. Metode survei adalah metode penelitian yang digunakan dalam penelitian ini.

Teknik pengambilan sampel dilakukan dengan Metode Multistage Random Sampling merupakan kombinasi dari sistem random sampling dan proportionate. Jumlah responden di ambil 80 peternak sapi potong rakyat. Teknik pengumpulan data dilakukan melalui wawancara langsung menggunakan kuesioner dan observasi langsung. Data yang diambil berupa data primer dan sekunder. Data primer diperoleh dari survey langsung ke lapangan dan hasil wawancara dengan menggunakan bantuan kuesioner. Data sekunder diambil dari instansi maupun dinas terkait.

Analisis data dilakukan dengan metode deskriptif kuantitatif yaitu metode yang menggambarkan tentang hal-hal yang berhubungan dengan judul dalam penelitian ini berupa manajemen pakan dan analisis profitabilitas usaha peternakan sapi potong di Kabupaten Langkat. Analisis data untuk manajemen pakan diperoleh dari mengidentifikasi masalah dan wawancara dari peternak dengan menggunakan kuesioner. Data yang diperoleh dianalisis secara deskriftif. Analisa profitabilitas dibutuhkan data keuangan yaitu biaya pembuatan kandang, penjualan sapi potong, biaya listrik, tenaga kerja, inseminasi buatan. Data yang diperoleh ditabulasi dianalisis dengan menggunakan analisis pendapatan dan profitabilitas (Soekardono, 2010).

Analisis pendapatan usaha ternak sapi menurut Soekartawi (2002), dapat dituliskan sebagai berikut:

Pendapatan $\pi=$ TR - TC .............. 1

$\Pi=$ Penerimaan Penjualan

$\mathrm{TR}=$ Total Revenue

$\mathrm{TC}=$ Total Cost

Selanjutnya dilakukan analisis profitabilitas yaitu perbandingan pendapatan dengan biaya dalam persentase.

$$
\text { Profitablitas }=\frac{\text { Pendapatan }}{\text { Biaya }} \times 100 \% \ldots \ldots \ldots .2
$$

Keterangan:

a. Profitabilitas lebih besar dari tingkat suku bunga deposito bank maka usaha ternak sapi potong dinyatakan menguntungkan

b. Profitabilitas lebih kecil dari tingkat suku bunga deposito bank maka usaha ternak sapi potong dinyatakan tidak menguntungkan

Perbedaan antara nilai profitabilitas dibandingkan dengan suku bunga berlaku dianalisis dengan menggunakan one sample t-test.

\section{Hasil dan Pembahasan \\ Keadaan Umum Kabupaten Langkat}

Kabupaten Langkat adalah salah satu wilayah yang berada di Sumatera Utara. Luas daerah kabupaten langkat sebesar +- 6.263,29 Km² (626.329 Ha) meliputi 23 kecamatan, 240 desa dan 37 kelurahan. Perbatasan kabupaten Langkat Sebelah selatan berbatasan dengan Kabupaten Karo. Sebelah Utara berbatasan dengan Aceh Tamiang dan Selat Malaka. Sebelah Timur berbatasan dengan Kota Binjai dan Kabupaten Deli Serdang. Sebelah Barat berbatasan dengan Provinsi Aceh.

\section{Manajemen Pakan \\ Jenis Pakan yang diberikan}

Pakan yang diberikan ke ternak sapi meliputi bahan pakan penguat (konsentrat), pakan berserat (rumput) dan bahan pakan tambahan (vitamin dan mineral) (Utomo, 2012). Keuntungan yang diperoleh peternak dipengaruhi oleh pemberian pakan dan pakan yang diberikan kepada ternak harus diperhatikan ekonomis dan kualitas. Bahan pakan yang diberikan kepada ternak dalam bentuk segar adalah hijauan, pakan yang terdiri dari limbah hasil proses industri 
pengolahan pangan dan biji-bijian yang mampu membuat pakan yang berkualitas rendah menjadi pakan yang mempunyai kandungan nutrisi yang tinggi supaya dapat memenuhi kandungan nutrisi ternak adalah konsentrat (Akoso, 2009). Pakan yang diberikan peternak kepada sapi potong hanya terdiri dari rumput. Rumput yang diberikan adalah rumput gajah, rumput lapang dan rumput odot. Peternak di Kabupaten Langkat hanya memberikan rumput kepada ternak karena keterbatasan modal untul membeli konsentrat dan kurangnya pengetahuan peternak terhadap pengaruh pemberian konsentrat bagi ternak. Pemberian pakan dengan hijauan dilakukan secara turun temurun. Peternak masih bersifat tradisional diperlukan penyuluhan yang rutin untuk memperkenalkan pemberian konsentrat kepada ternak.

\section{Pemberian Pakan}

Pemberian Pakan yang diberikan peternak kepada ternak adalah dua kali sehari yaitu pagi dan sore hari. Pagi hari diberikan jam 06.00 WIB dan pemberian pakan sore hari jam 18.00 WIB. Jarak pemberian pakan yaitu 12 jam. Jumlah pakan yang diberikan disesuaikan dengan umur ternak yaitu pedet, dara, jantan, dan induk. Pakan yang diberikan ke pedet sebanyak $5 \mathrm{~kg} /$ ekor/hari, dara sebanyak $15 \mathrm{~kg} /$ ekor/hari, induk dan pejantan sebanyak $25 \mathrm{~kg} / \mathrm{ekor} / \mathrm{hari}$. Walaupun pemberian pakan hanya terdiri dari hijauan, sapi tumbuh dengan sehat dan besar. Hal ini sesuai dengan pendapat Siregar (2008), menyatakan bahwa semakin sering pemberian pakan hijauan pada ternak akan mendorong kecernaan bahan kering menjadi tinggi, meningkatnya kecernaan bahan kering ransum akan menambah kandungan nutrisi yang digunakan untuk produksi termasuk pertumbuhan.

\section{Cara Pemberian}

Peternak di Kabupaten Langkat memberikan pakan dengan cara kreman (dry lot fattening). Metode kreman adalah metode yang memelihara sapi potong hanya didalam kandang, tidak ada penggembalaan sapi dengan metode ini. Sapi dipelihara secara intensif yaitu didalam kandang. Tujuan dari metode ini adalah agar sapi memperoleh berat badan yang tinggi karena tidak melakukan exercise seperti di padang penggembalaan. Menurut Sandi et al., (2019), menyatakan bahwa cara pemberian pakan di Desa Sejaro Sakti dengan kombinasi yaitu penggembalaan dan kereman merupakan cara pemberian pakan yang terbaik. Peternak didaerah ini menerapkan dengan cara kombinasi tetapi mengalami kelemahan karna pakan yang diberikan hanya sesuai ketersediaan.

\section{Analisis Profitabilitas Usaha Peternakan Sapi Potong Penerimaan}

Hasil penelitian peternak bersumber dari penjualan sapi potong terdiri dari penjualan pedet, dara, sapi pejantan dan induk. Penjualan pedet sebesar Rp 225.000; penjualan sapi dara sebesar Rp 968.750, Penjualan sapi pejantan sebesar Rp 11.647.500 dan sapi induk sebesar Rp 3.281.250 (Tabel 1). Penjualan terbesar diperoleh dari penjualan sapi pejantan. Penjualan sapi induk terjadi karena induk sudah tidak mampu melakukan reproduksi dan usia sudah tua. Penjualan pedet dan dara di karenakan peternak memerlukan dana untuk memenuhi kebutuhan sehingga menjual dara dan pedet. Selama pandemi penjualan ternak mengalami penurunan harga berkisar Rp 1.000.000 - Rp. 1.500.000. Sebagian peternak memilih untuk tetap memelihara ternak hingga harga di pasar kembali stabil dan menunggu moment idul adha supaya harga jual ternak bisa normal. Pemberlakuan new normal membuat harga jual menjadi stabil. Harga jual ternak sapi potong berdasarkan bobot hidup ternak pada saat di lakukan penjualan. Hal ini sesuai dengan pendapat Haloho \& Saragih (2021), bahwa harga jual sapi potong bergantung pada bobot hidup saat terjadinya proses penjualan.

Tabel 1. Rata-rata Penerimaan Usaha Peternakan Sapi Potong Rakyat

\begin{tabular}{clc}
\hline No & Keterangan & Jumlah $(\mathrm{Rp})$ \\
\hline & Penerimaan dari penjualan & \\
1 & Pedet jantan & 225.000 \\
2 & Sapi Dara & 968.750 \\
3 & Sapi pejantan & 11.647 .500 \\
4 & Sapi induk & 3.281 .250 \\
\hline & Total Penerimaan & 16.122 .500
\end{tabular}

Sumber: Data Primer diolah tahun 2021

\section{Biaya Produksi Usaha Peternakan Sapi Potong Rakyat}

Biaya produksi yang dikeluarkan terbagi dua yaitu biaya tetap dan biaya tidak tetap. Biaya tetap yaitu biaya tetap non tunai terdiri dari biaya depresiasi peralatan sebesar Rp 25.819; depresiasi kandang sebesar 362.138 dan biaya listrik sebesar Rp 30.875 (Tabel 2). Total biaya 
tetap sebesar Rp 418.831. Biaya tidak tetap yaitu biaya tidak tetap tunai dan non tunai terdiri dari biaya cash yaitu Inseminasi buatan sebesar Rp 423.750, Biaya tidak tetap non cash terdiri dari pakan hijauan sebesar Rp 4.131.000 serta biaya tenaga kerja sebesar Rp 7.416.000. Total biaya tidak tetap sebesar Rp 11.970.750. Biaya tidak tetap terbesar yaitu biaya tenaga kerja sebesar Rp 7.416.000 dan biaya pakan hijauan sebesar Rp 4.131.000.

Biaya tenaga kerja dihitung berdasarkan standart upah yang berlaku yaitu sebesar Rp 8.000 untuk satu ekor ternak per hari. Tugas dari tenaga kerja adalah memberi pakan kepada sapi, sanitasi sapi dan kandang. Pekerjaan ini dilakukan pada pagi dan sore hari. Menurut Handayanta et al., (2016), menyatakan bahwa biaya tenaga kerja merupakan komponen kedua terbesar dari biaya produksi usaha sapi potong. Biaya pakan hijauan tidak mengalami kenaikan harga saat pandemi. Biaya inseminasi yang dikeluarkan sebesar Rp 423.750. Biaya untuk satu kali inseminasi sebesar Rp 100.000. Inseminasi buatan yang dilakukan hingga sapi bunting bisa lebih dari dua kali. Hal ini yang menyebabkan biaya untuk inseminasi cukup tinggi.

Tabel 2. Rata-rata Biaya Produksi Usaha Peternakan Sapi Potong Rakyat

\begin{tabular}{|c|c|c|c|c|}
\hline \multirow{2}{*}{ No } & \multirow{2}{*}{ Uraian } & \multicolumn{2}{|c|}{ Biaya Produksi } & \multirow{2}{*}{ Total Biaya (Rp) } \\
\hline & & Cash (Rp) & Non cash (Rp) & \\
\hline & Biaya Tetap & & & \\
\hline 1 & Depresiasi Peralatan & & 25.819 & \\
\hline 2 & Depresiasi Kandang & & 362.138 & \\
\hline \multirow{3}{*}{3} & Listrik & & 30.875 & \\
\hline & Total biaya tetap & & 418.831 & 418.831 \\
\hline & Biaya Tidak tetap & & & \\
\hline 1. & Pakan Hijauan & & 4.131 .000 & \\
\hline 2 & Tenaga Kerja & & 7.416 .000 & \\
\hline \multirow[t]{3}{*}{3} & Inseminasi Buatan & 423.750 & & \\
\hline & Total Biaya Tidak Tetap & 423.750 & 11.547 .000 & 11.970 .750 \\
\hline & Total Biaya & 423.750 & 11.965 .831 & 12.389 .581 \\
\hline
\end{tabular}

Sumber: Data Primer diolah tahun 2021

\section{Analisis Profitabilitas Usaha Peternakan Sapi Potong rakyat}

Berdasarkan Tabel 3. Profitabilitas usaha peternakan sapi potong adalah penerimaan yangdiperoleh sebesar Rp 16.122.500. Biaya produksi sebesar Rp12.389.581. Besarnya pendapatan yang diperoleh sebesar Rp 3.732.919. Profitabilitas yang diperoleh sebesar 23,15\% per tahun.

Usaha peternakan sapi potong di Kabupaten Langkat masih menguntungkan. Hal ini dapat dilihat dari bunga deposito Bank BRI Tahun 2020 sebesar 4\% per tahun. Berdasarkan penelitian Haloho (2020), bahwa profitabilitas usaha peternakan sapi potong di Binjai menguntungkan karena nilai profitabilitas lebih tinggi dari tingkat suku bunga bank. Usaha peternakan sapi potong rakyat layak untuk dijalankan karena menghasilkan keuntungan.

Tabel 3. Analisis Profitabilitas Usaha Peternakan Sapi potong

\begin{tabular}{lll}
\hline No & Uraian & Jumlah $(\mathrm{Rp})$ \\
\hline 1 & Penerimaan & 16.122 .500 \\
2 & Biaya Produksi & 12.389 .581 \\
3 & Pendapatan & 3.732 .919 \\
\hline & Profitabilitas & $23,15 \%$ \\
\hline
\end{tabular}

Sumber: Data Primer diolah tahun 2021

\section{Analisis One Sampel T-test}

Analisis yang digunakan untuk mengetahui pengamatan data dengan asumsi rata-rata suatu variable dengan konstanta atau nilai hipotesis menggunakan analisis one sample t-test (Trihendradi, 2019). Analisis One Sampel T-Test digunakan untuk mengetahui apakah usaha sapi potong rakyat menguntungkan dengan melakukan perbandingan antara nilai profitablitas dengan deposito Bank BRI sebesar 4\%. Berdasarkan hasil perhitungan nilai sig profitabilitas usaha ternak sapi potong sebesar $(0,000)$ berarti profitabilitas usaha peternakan sapi potong rakyat berbeda sangat nyata dengan Bunga Deposito Bank BRI yang berlaku sehingga usaha menguntungkan dan layak untuk dikembangkan. 


\begin{tabular}{|c|c|c|c|c|c|c|}
\hline & \multicolumn{6}{|c|}{ Test Value $=4$} \\
\hline & \multirow[b]{2}{*}{$\mathrm{T}$} & \multirow[b]{2}{*}{ Df } & \multirow[b]{2}{*}{ Sig. (2-tailed) } & \multirow{2}{*}{$\begin{array}{c}\text { Mean } \\
\text { Difference }\end{array}$} & \multicolumn{2}{|c|}{$\begin{array}{l}\text { 95\% Confidence Interval of the } \\
\text { Difference }\end{array}$} \\
\hline & & & & & Lower & Upper \\
\hline Profitabilitas & 4.951 & 79 & .000 & 55.41612 & 33.1386 & 77.6936 \\
\hline
\end{tabular}

\section{Simpulan}

Manajemen pakan yaitu pakan yang diberikan hanya terdiri dari hijauan, pemberian pakan diberikan pada pagi dan sore hari dan cara pemberian pakan dengan metode kreman. Berdasarkan hasil perhitungan selama pandemi covid 19, jumlah penerimaan sebesar Rp 16 . 122.500; biaya produksi sebesar Rp 12.389.581. Besarnya pendapatan peternak sapi potong rakyat sebesar Rp 3.732.919. Nilai Profitabilitas sebesar 23,15\% lebih besar dari deposito Bank BRI sebesar 4\% maka usaha sapi potong dinyatakan menguntungkan dan layak dikembangkan. Pemberian pakan yang cukup mampu memberikan keuntungan kepada peternak.

\section{Saran}

Bagi peternak direkomendasikan menerapkan manajemen pakan yang lebih baik lagi, pakan yang diberikan kepada ternak bukan hanya hijauan tetapi juga konsentrat. Pemberian konsentrat dapat meningkatkan produksi daging. Jika ternak menghasilkan bobot badan yang tinggi maka akan meningkatkan harga jual. Pemberian pakan yang baik akan meningkatkan profitabilitas peternak sapi potong. Bagi Dinas Pertanian dan Ketahanan Pangan Langkat bisa dibuat pakan konsentrat bagi peternak yang terjangkau dan bernutrisi tinggi supaya peternak mampu memberikan pakan konsentrat bagi ternak.

\section{Pustaka}

Akoso, B.T. 2009. Epidemologi dan Pengendalian Antraks, Kanisius. Yogyakarta.

Agustini, N. 2010. Petunjuk Praktis Manajemen Pengelolaan Limbah Pertanian Untuk Pakan Ternak Sapi. Balai Pengkajian Teknologi Pertanian NTB. Kementerian Pertanian

Direktorat Jenderal Peternakan dan Kesehatan Hewan. 2020. Statistik Peternakan dan Ternak Kesehatan Hewan 2020. Direktorat Jenderal Peternakan dan Kesehatan Hewan. Jakarta.http://ditjenpkh.pertanian.go.id/index.html. Diakses 25 Mei 2021.

Dinas Ketahanan Pangan \& Peternakan Provinsi Sumatera Utara. 2020. Data Populasi Ternak Provinsi Sumatera Utara 2020. http://dishanpangternak.sumutprov.go.id/?page_id=580. diakses 25 Mei 2021.

Dinas peternakan dan kesehatan hewan. 2018. Kementerian Pertanian Direktorat Jenderal Peternakan dan kesehatan Hewan. http://ditjenpkh.pertanian.go.id. Di akses 07 Juli 2019.

Haloho, R. D. (2020). Business analysis of cattle fattening using agribusiness paradigm (case study at Molan beef cattle livestock) in West Binjai Regency, North Sumatera Province. AGRIMOR, 5(1). https://doi.org/10.32938/ag.v5i1.949

Haloho, R. D., \& Saragih, C. L. (2021). Analisis Kelayakan Usaha Peternakan Sapi Potong Rakyat di Kabupaten Langkat. AGRIMOR, 6(1). https://doi.org/10.32938/ag.v6i1.1189

Handayanta, E., Rahayu, E. T., \& Sumiyati, M. (2016). ANALISIS FINANSIAL USAHA PETERNAKAN PEMBIBITAN SAPI POTONG RAKYAT DI DAERAH PERTANIAN LAHAN KERING: Studi Kasus di Wilayah Kecamatan Semin, Kabupaten Gunungkidul, Daerah Istimewa Yogyakarta. Sains Peternakan, https://doi.org/10.20961/sainspet.v14i1.8770

Haq, M., Fitra, S., Madusari, S., \& Yama, D. . (2018). Potensi kandungan nutrisi pakan berbasis limbah pelepah kelapa sawit dengan teknik fermentasi. Prosiding Seminar Nasional Sains Dan Teknologi, 2015.

Harmen. (2020). Dampak Pandemi Covid-19 Terhadap Ketersediaan Pakan Ternak Di Sumatera Barat. $5(2)$

$130-147$. https://ejournal.sumbarprov.go.id/index.php/jpn/article/view/199/85

Lestari, R. D., Baga, L. M., \& Nurmalina, R. (2017). ANALISIS KEUNTUNGAN FINANSIAL USAHA PENGGEMUKAN SAPI POTONG DI KABUPATEN BOJONEGORO. SEPA: Jurnal Sosial Ekonomi Pertanian Dan Agribisnis, 11(2). https://doi.org/10.20961/sepa.v11i2.14180

Putri, G. N., Sumarjono, D., \& Roessali, W. (2019). ANALISIS PENDAPATAN USAHA SAPI POTONG POLA PENGGEMUKAN PADA ANGGOTA KELOMPOK TANI TERNAK BANGUNREJO II DI DESA POLOSIRI KECAMATAN BAWEN KABUPATEN SEMARANG. Agrisocionomics: Jurnal Sosial Ekonomi Pertanian, 3(1). 
https://doi.org/10.14710/agrisocionomics.v3i1.4509

Sandi, S., Desiarni, M., \& -, A. (2019). Manajemen Pakan Ternak Sapi Potong di Peternakan

Rakyat di Desa Sejaro Sakti Kecamatan Indralaya Kabupaten Ogan Ilir. Jurnal Peternakan Sriwijaya, 7(1). https://doi.org/10.33230/jps.7.1.2018.7080

Siregar. 2008. Ransum Ternak Ruminansia. Jakarta: Penebar Swadaya.

Soekardono. 2009. Ekonomi Agribisnis Peternakan Teori dan Aplikasinya, Akademika Pressindo, Jakarta.

Soekartawi. 2002. Prinsip Dasar Ekonomi Pertanian. Penerbit PT Raja Grafindo Persada, Jakarta.

Sunyoto, D. 2009. Analisis Regresi dan Uji Hipotesis. Media Pressindo. Yogyakarta.

Trihendradi, C. 2019. Langkah Mudah Melakukan Analisis Statistik Menggunakan SPSS 19. Penerbit Andi, Yogyakarta.

Utomo, R. 2012. Bahan Pakan Berserat untuk Sapi. Yogyakarta PT. Citra Aji Parama. 